\title{
Intracranial hemorrhage after high-dose methylprednisolone in a child with acute immune thrombocytopenic purpura
}

\author{
Katja M. J. Heitink-Pollé • Dirk Jan Pot • \\ Marjolein Engelkes • Marrie C. A. Bruin
}

Received: 18 August 2010 / Accepted: 2 February 2011 /Published online: 18 February 2011

(C) The Author(s) 2011. This article is published with open access at Springerlink.com

Dear Editor,

Severe hemorrhage in children with immune thrombocytopenic purpura (ITP) is rare and occurs in 3\% of patients [1]. Intracranial hemorrhage (ICH), the most feared bleeding complication, has an estimated incidence of $0.1-0.5 \%$ [1-3]. Mortality rate of $\mathrm{ICH}$ is high and varies from $24-57 \%$ [2-4]. We report a patient with acute ITP who developed fatal ICH shortly after starting highdose methylprednisolone.

A 5-year-old girl with an unremarkable medical and family history presented to her pediatrician with acute onset of bruising and petechiae. Physical examination revealed no other abnormalities. Blood pressure was 112/ $60 \mathrm{mmHg}$. Laboratory studies showed an isolated trombocytopenia of $1 \times 10^{9} / \mathrm{L}$ (Table 1 ). She was diagnosed with acute ITP and managed conservatively. Four days after presentation, she developed large ecchymoses and epistaxis causing anemia. Intravenous immunoglobulins (IVIg; $0.8 \mathrm{~g} / \mathrm{kg}$ once) and packed red cells were administered (Fig. 1). Platelet count remained low $\left(1 \times 10^{9} / \mathrm{L}\right)$

K. M. J. Heitink-Pollé $(\bowtie) \cdot$ M. C. A. Bruin Department of Pediatric Hematology-Oncology, University Medical Center Utrecht/Wilhelmina Children's Hospital, KC 03.063.0, Postbox 85090, 3508 AB Utrecht, The Netherlands e-mail: kheitink@umcutrecht.nl

D. J. Pot $\cdot$ M. Engelkes

Department of Pediatrics, Gelre Ziekenhuizen,

Apeldoorn, The Netherlands and mucosal bleeding continued. The girl was referred to our department for further management. We saw a pale, tachycardic girl with multiple ecchymoses and active mucosal bleeding from nose and mouth. Hemoglobin was $7.4 \mathrm{~g} / \mathrm{dL}$ and platelet count $2 \times 10^{9} / \mathrm{L}$. After a second gift of IVIg, prednisone $2 \mathrm{mg} / \mathrm{kg} /$ day, an erythrocyte transfusion and a large dose of platelets (ten donor units), platelet count rose to $21 \times 10^{9} / \mathrm{L}$, hemoglobin stabilized and the clinical condition of our patient improved dramatically. However, $36 \mathrm{~h}$ later, profuse mucosal bleeding from nose and mouth recurred at a platelet count of $1 \times 10^{9} / \mathrm{L}$. We started high-dose methylprednisolone $(15 \mathrm{mg} / \mathrm{kg})$ together with another platelet transfusion. Shortly after starting the methylprednisolone infusion, she complained of severe headache and instantly developed generalized seizures. Blood pressure at that moment was elevated: $170 / 90 \mathrm{mmHg}$. Computed tomography (CT) showed extensive bifrontal ICH. Unfortunately, our patient died of progressive herniation caused by massive cerebral edema, despite continuous platelet transfusions and intensive care management. Autopsy was not performed.

The main reason for clinicians to treat children with acute ITP and minor bleeding symptoms is to raise platelet counts in order to prevent severe bleeding complications and in particular ICH. The question is whether treatment really prevents these bleeding complications. The majority of children with severe bleeding or $\mathrm{ICH}$ described in literature developed these complications despite prior therapy [1-5]. Why do some patients develop ICH despite therapy? Apart from known risk factors like head trauma, use of non-steroidal anti- 
Table 1 Results of laboratory studies in our patient

\begin{tabular}{|c|c|c|c|c|c|c|c|c|c|c|}
\hline & Diagnosis & Day 4 & Day 5 & Day 6 & Day 7 & Day 8 & $\begin{array}{l}\text { Day } 9(1 \mathrm{~h} \\
\text { after ICH })\end{array}$ & $\begin{array}{l}\text { Day } 9(5 \mathrm{~h} \\
\text { after ICH) }\end{array}$ & $\begin{array}{l}\text { Day } 10 \text { (at moment } \\
\text { of herniation) }\end{array}$ & Units \\
\hline Hemoglobin & 11.6 & 5.8 & 11.3 & 7.4 & 8.6 & 10.6 & 9.0 & 6.4 & & $\mathrm{~g} / \mathrm{dL}$ \\
\hline Hematocrit & 0.32 & 0.17 & 0.32 & & 0.23 & 0.28 & 0.24 & 0.17 & & $\mathrm{~L} / \mathrm{L}$ \\
\hline Platelets & 1 & 1 & 1 & 2 & 21 & 1 & 3 & 129 & 16 & $\times 10^{9} / \mathrm{L}$ \\
\hline Leukocytes & 12.7 & 7.5 & 10.6 & 14.0 & 12.6 & 15.6 & 25.1 & & & $\times 10^{9} / \mathrm{L}$ \\
\hline Neutrophils & 8.9 & 5.4 & 5.3 & & & & & & & $\times 10^{9} / \mathrm{L}$ \\
\hline Lymphocytes & 2.8 & 1.9 & 3.9 & & & & & & & $\times 10^{9} / \mathrm{L}$ \\
\hline $\begin{array}{l}\text { Activated partial } \\
\text { thromboplastin } \\
\text { time (APTT) }\end{array}$ & 29 & & & 29 & & & & 24 & & $\mathrm{~s}$ \\
\hline Prothrombin time $(\mathrm{PT})$ & 12.7 & & & 14.4 & & & & $<10$ & & $\mathrm{~s}$ \\
\hline Coombs test & & Negativ & & Negativ & & & & & & \\
\hline
\end{tabular}

ICH Intracranial hemorrhage

inflammatory drugs, intracranial arteriovenous malformation, and bleeding beyond petechiae and ecchymoses [2, 3], there are some other possible explanations. Patients may suffer from refractory ITP and remain severely thrombocytopenic despite therapy, leaving them at risk for bleeding complications [6]. However, there is also a possibility of either causing or worsening ICH due to adverse effects of drug therapy. In our patient, the temporal relationship between starting methylprednisolone and development of headache and ICH remains remarkable. A sudden rise in blood pressure, a known adverse effect of high-dose methylprednisolone, could have initiated or worsened ICH.

In conclusion, this report shows that treatment of ITP cannot always prevent ICH and may even be involved in initiating or worsening $\mathrm{ICH}$.
Fig. 1 Overview of platelet counts and interventions in our patient. $i=\mathrm{IVIg}$; white bar $=$ prednisone $2 \mathrm{mg} / \mathrm{kg} /$ day; white arrow $=$ high-dose methylprednisolone infusion; black circle $=$ platelet transfusion; black diamond $=$ erythrocyte transfusion. Lightning flash $=$ event: the first one represents onset of $\mathrm{ICH}$, the second one brain herniation

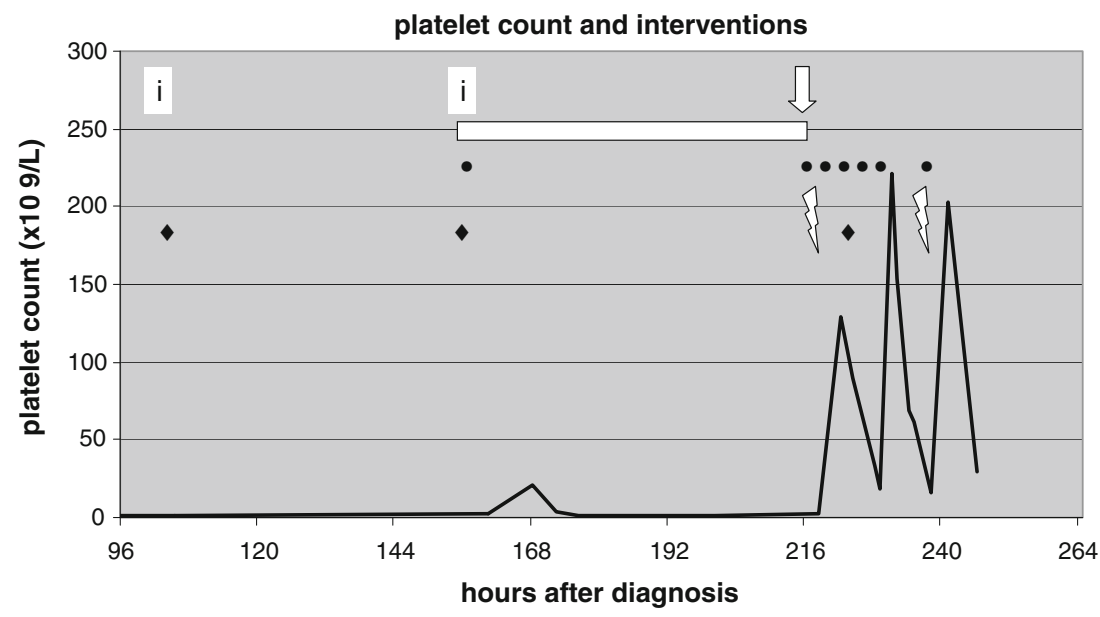


Open Access This article is distributed under the terms of the Creative Commons Attribution Noncommercial License which permits any noncommercial use, distribution, and reproduction in any medium, provided the original author(s) and source are credited.

\section{References}

1. Neunert CE, Buchanan GR, Imbach P, Bolton-Maggs PH, Bennett CM, Neufeld EJ, Vesely SK, Adix L, Blanchette VS, Kuhne T (2008) Severe hemorrhage in children with newly diagnosed immune thrombocytopenic purpura. Blood 112:4003-4008

2. Lilleyman JS (1994) Intracranial haemorrhage in idiopathic thrombocytopenic purpura. Paediatric Haematology Forum of the British Society for Haematology. Arch Dis Child 71:251-253
3. Psaila B, Petrovic A, Page LK, Menell J, Schonholz M, Bussel JB (2009) Intracranial hemorrhage (ICH) in children with immune thrombocytopenia (ITP): study of 40 cases. Blood 114:4777-4783

4. Choudhary DR, Naithani R, Mahapatra M, Kumar R, Mishra $P$, Saxena R (2009) Intracranial hemorrhage in childhood immune thrombocytopenic purpura. Pediatr Blood Cancer 52:529-531

5. Iyori H, Bessho F, Ookawa H, Konishi S, Shirahata A, Miyazaki S, Fujisawa K, Akatsuka J (2000) Intracranial hemorrhage in children with immune thrombocytopenic purpura. Japanese Study Group on childhood ITP. Ann Hematol 79:691-695

6. Medeiros D, Buchanan GR (1998) Major hemorrhage in children with idiopathic thrombocytopenic purpura: immediate response to therapy and long-term outcome. J Pediatr 133: 334-339 